\title{
SALINE WATER AND POTASSIUM FERTILIZATION IN CULTIVATION OF GRAFTED WEST INDIAN CHERRY 'BRS 366 JABURU'
}

\author{
ÁGUAS SALINAS E ADUBAÇÃO POTÁSSICA NO CULTIVO DE ACEROLEIRA 'BRS \\ 366 JABURU' ENXERTADA
}

\begin{abstract}
Francisco Wesley Alves PINHEIRO'혀 Geovani Soares de LIMA ${ }^{2}$; Hans Raj GHEYI ${ }^{3}$; Adaan Sudário DIAS ${ }^{1}$; Rômulo Carantino Lucena MOREIRA ${ }^{1}$; Reginaldo Gomes NOBRE; Lauriane Almeida dos Anjos SOARES ${ }^{5}$

1. Doutorando em Engenharia Agrícola, Universidade Federal de Campina Grande-UFCG, Campina Grande, PB, Brasil; 2. Professor Visitante, UFCG, Unidade Acadêmica de Ciências Agrárias, Pombal, PB, Brasil. geovanisoareslima@ gmail.com; 3. Professor Visitante, Universidade Federal do Recôncavo da Bahia, Cruz das Almas, BA, Brasil; 4. Professor, Doutor, Universidade Federal Rural do Semiárido, Caraúbas, RN, Brasil 5. Professora, Doutora, UFCG, Unidade Acadêmica de Ciências Agrárias, Pombal, PB, Brasil.
\end{abstract}

\begin{abstract}
Agricultural exploitation in the semi-arid region of Northeast Brazil depends on the use of irrigation to guarantee safe production of crops. Nevertheless, the waters commonly used in this region have high levels of salts and require management strategies that make their use possible in agriculture. In this context, the present study aimed to evaluate water relations, photosynthetic pigments and growth of grafted West Indian cherry as a function of saline water irrigation and potassium (K) fertilization. The study was conducted under greenhouse conditions in lysimeters filled with eutrophic Regolithic Neosol with sandy loam texture, in the municipality of Campina Grande-PB, Brazil. Treatments were distributed in randomized blocks and consisted of two factors: two levels of irrigation water electrical conductivity - $\mathrm{ECw}\left(0.8\right.$ and $\left.3.8 \mathrm{dS} \mathrm{m}^{-1}\right)$ and four $\mathrm{K}$ doses $(50,75 ; 100$ and $125 \%$ of the recommendation), with three replicates and one plant per plot. The $100 \%$ dose corresponded to $19.8 \mathrm{~g}$ of $\mathrm{K}_{2} \mathrm{O}$ per plant per year. The West Indian cherry crop was sensitive to water salinity of $3.8 \mathrm{dS} \mathrm{m}^{-1}$ in the post-grafting phase, resulting in a decline in photosynthetic pigment content and growth. Increasing $\mathrm{K}$ doses reduced the percentage of cell membrane damage and promoted increase in the synthesis of chlorophyll $a$ and carotenoids in West Indian cherry plants. There was significant interaction between salinity levels and $\mathrm{K}$ doses for the leaf osmotic potential, water saturation deficit, percentage of cell membrane damage and chlorophyll $b$ content in West Indian cherry plants.
\end{abstract}

KEYWORDS: Malphigia emarginata. Saline stress. Osmoregulation.

\section{INTRODUCTION}

West Indian cherry (Malpighia emarginata D.C.) is widely known as a fruit that stands out for its high content of vitamin $\mathrm{C}$, with contents of ascorbic acid ranging from 695 to $4827 \mathrm{mg}_{100 \mathrm{~g}^{-1}}$ (MEZADRI et al., 2006), attributes that have increased its consumption not only in human diet, but also in the pharmaceutical industry. Besides ascorbic acid, other important bioactive compounds have been found, such as phenolic compounds, natural dyes, compounds with recognized action in the prevention of degenerative diseases, biological activity and health maintenance (DEMBITSKY et al., 2011).

Brazil is one of the three largest fruit producers of the world. Its production exceeds 40 million tons, which represents $5 \%$ of the global production, only behind China and India. Approximately $53 \%$ of the Brazilian production is intended for the market of processed fruits and $47 \%$ for the market of fresh fruits (ISOLDA et al., 2014).
In Brazil, the Northeast is the main producing region, with $64 \%$ of the cultivated area in the country, corresponding to a mean yield of $15,360 \mathrm{~kg}$ $\mathrm{ha}^{-1}$ year $^{-1}$ (ADRIANO et al., 2011; ESASHIKA et al., 2013).

Nonetheless, the semi-arid region of Northeast Brazil is subject to agroclimatic variation, and high temperatures, low rainfall, irregular rainfall and high evaporation rates in most of the year are common, resulting in the scarcity of surface waters. The practice of irrigation is an important measure to guarantee water supply in moments of greater demands (NOBRE et al., 2011).

Despite the importance of irrigation, part of the water sources available usually have high contents of salts, particularly chloride and sodium (NEVES et al., 2009; JIANG et al., 2012). High concentrations of salts in the water and/or soil can cause many physiological effects, leading to reduction of growth and disorders in membrane permeability, water exchange activity, stomatal 
conductance and photosynthesis (NAVARRO et al., 2003; CABANERO et al., 2004).

Information on the tolerance of the West Indian cherry crop to the salinity, despite the great socioeconomic interest involved, are still scarce, especially in the Brazilian semiarid conditions. Gurgel et al. (2003) evaluating the physiology and the growth of the BV1 arsenic clone, as a function of salinity ( $\mathrm{ECw}$ ranging from 0.5 to $5.5 \mathrm{dS} \mathrm{m}^{-1}$ ), in the stage of scion grafting, observed that the increase of salinity in irrigation water inhibited the absolute and relative growth rates and the net assimilation of the West Indian cherry plant in the period from 50 to 90 days after emergence (DAE) of the first seedling. In another research, Gurgel et al. (2007) found that the study of the effects of the use of waters of different salinities on the production of saplings, involving stages of rootstock formation, grafting and development of the plants until the transplant phase, water salinity up to $5.5 \mathrm{dS} \mathrm{m}^{-1}$ did not affect the growth of the West Indian cherry seedlings until the transplant phase.

Therefore, in an attempt to mitigate the deleterious effects on the crops caused by the excess of salts in irrigation water and/or soil, and to make viable the use of lower-quality waters in regions with limited water resources, several practices have been developed. Among these practices, fertilization stands out, based on the use of fertilizers that favor the acquisition of nutrients by plants under saline conditions (SILVA et al., 2011). Studies conducted by Gurgel et al. (2010) and Sá et al. (2016) found reductions in the negative effects of high-salinity water with the use of potassium fertilization in melon and cotton crops, respectively.

Potassium is vital for photosynthesis and, in situations of deficiency, its deficiency causes reduction in photosynthetic rate and increase in respiration, resulting in the reduction of carbohydrate accumulation (NOVAIS et al., 2007). Potassium favors the formation and translocation of carbohydrates and its efficient use improves the product's quality and, consequently, its market value (FILGUEIRA, 2005). In addition, potassium is related to cell turgor, osmotic potential, stomatal opening and closure, besides being involved also in plant defense mechanisms against pests and diseases, because greater potassium availability promotes metabolic changes that lead to higher production of starch, cellulose and proteins, lower concentration of nitrate, sugars and amino acids in the plants, which imparts higher resistance to pathogens (ROMHELD, 2005).

In this context, this study aimed to evaluate water relations, photosynthetic pigments and growth of grafted West Indian cherry as a function of saline water irrigation and potassium $(\mathrm{K})$ fertilization.

\section{MATERIAL AND METHODS}

The study was carried out in pots adopted as drainage lysimeters under greenhouse conditions, from July 2016 to July 2017, at the Center of Technology and Natural Resources of the Federal University of Campina Grande (CTRN/UFCG), located in the municipality of Campina Grande-PB, Brazil, at local geographic coordinates $7^{\circ} 15^{\prime} 18^{\prime \prime} \mathrm{S}$, $35^{\circ} 52^{\prime} 28^{\prime \prime}$ 'W and altitude of $550 \mathrm{~m}$.

The experimental design was randomized blocks, with three replicates, using a $2 \times 4$ factorial arrangement. Treatments consisted of two levels of irrigation water electrical conductivity - $\mathrm{ECw}(0.8$ and $3.8 \mathrm{dS} \mathrm{m}^{-1}$ ) and four $\mathrm{K}$ doses $(50,75 ; 100$ and $125 \%$ of the recommendation of MUSSER, 1995). The dose relative to $100 \%$ corresponded to $19.8 \mathrm{~g}$ of $\mathrm{K}_{2} \mathrm{O}$ per plant per year.

Irrigation water with the $\mathrm{ECw}$ of $3.8 \mathrm{dS} \mathrm{m}^{-1}$ was prepared by dissolving the salts $\mathrm{NaCl}$, $\mathrm{CaCl}_{2} \cdot 2 \mathrm{H}_{2} \mathrm{O}$ and $\mathrm{MgCl}_{2} \cdot 6 \mathrm{H}_{2} \mathrm{O}$, at equivalent proportion of 7:2:1, respectively, in water $(\mathrm{ECw}=$ $1.40 \mathrm{dS} \mathrm{m}^{-1}$ ) from the public supply system of Campina Grande-PB, based on the relationship between $\mathrm{ECw}$ and the concentration of salts $\left(\mathrm{mmol}_{\mathrm{c}}\right.$ $\mathrm{L}^{-1}=10^{*} \mathrm{ECW} \mathrm{dS} \mathrm{m}{ }^{-1}$ ) according to Richards (1954). The water with ECw of $0.8 \mathrm{dS} \mathrm{m}^{-1}$ was obtained by diluting public-supply water in rainwater.

At the bottom of each lysimeter, a 4-mmdiameter tube was installed to drain the excess water into a collector, in order to evaluate the drained water and determine plant water consumption. The tip of the drain inside the pot was involved in nonwoven geotextile (Bidim OP 30) to avoid clogging by soil material.

The lysimeters were filled with a $1-\mathrm{kg}$ layer of crushed stone (zero size), followed by $250 \mathrm{~kg}$ of eutrophic Regolithic Neosol of sandy loam texture (0-20 cm depth), properly pounded to break up clods, from the rural area of the municipality of Esperança-PB. Its physical and chemical characteristics (Table 1) were obtained according to methodologies proposed by Donagema et al. (2011).

'Crioula' West Indian cherry seedlings were used as rootstock in the present study, provided by the EMBRAPA Tropical Agroindustry, located in Pacajus-CE. The seedlings were transplanted at the age of 240 days. During the acclimation period in the greenhouse, West Indian cherry plants were irrigated with low-salinity water $\left(0.8 \mathrm{dS} \mathrm{m} \mathrm{m}^{-1}\right)$. The cultivar 'BRS 366 Jaburu' was used as scion. This cultivar stands out for its high yield $\left(57 \mathrm{t} \mathrm{ha}^{-1}\right)$, 
which favors the production of vitamin $\mathrm{C}(2,648 \mathrm{mg}$ $\left.100 \mathrm{~g}^{-1}\right)$. Plants are approximately $1.87 \mathrm{~m}$ tall, with crown diameter of $2.18 \mathrm{~m}$. Its fruits are bright when ripe; they weigh 4 to $5 \mathrm{~g}$ in the green-colored stage, adequate to obtain vitamin $\mathrm{C}$, and 6 to $7 \mathrm{~g}$, after ripening (EMBRAPA, 2012).

Table 1. Physical and chemical characteristics of the soil used in the experiment.

\begin{tabular}{|c|c|c|c|c|c|c|c|c|}
\hline \multicolumn{9}{|c|}{ Chemical characteristics } \\
\hline \multirow{2}{*}{$\begin{array}{l}\mathrm{pH} \\
\left(\mathrm{H}_{2} \mathrm{O}\right) \\
(1: 2,5) \\
\end{array}$} & \multirow{2}{*}{$\begin{array}{l}\text { O. M. } \\
\mathrm{g} \mathrm{kg}^{-1}\end{array}$} & \multirow{2}{*}{$\begin{array}{c}\mathrm{P} \\
\left(\mathrm{mg} \mathrm{kg}^{-1}\right)\end{array}$} & \multirow[t]{2}{*}{$\mathrm{K}^{+}$} & \multirow[t]{2}{*}{$\mathrm{Na}^{+}$} & \multirow[t]{2}{*}{$\mathrm{Ca}^{2+}$} & \multirow[t]{2}{*}{$\mathrm{Mg}^{2+}$} & \multirow[t]{2}{*}{$\mathrm{Al}^{3+}$} & \multirow[t]{2}{*}{$\mathrm{H}^{+}$} \\
\hline & & & & & & & & \\
\hline 5.58 & 2.93 & 39.2 & 0.23 & 1.64 & 9.07 & 2.78 & 0.00 & 8.61 \\
\hline \multicolumn{4}{|c|}{.......... Chemical characteristics............ } & \multicolumn{5}{|c|}{ 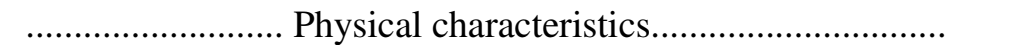 } \\
\hline ECse & CEC & SAR & ESP & \multicolumn{3}{|c|}{ Size fraction $\left(\mathrm{g} \mathrm{kg}^{-1}\right)$} & \multicolumn{2}{|c|}{ Water content $\left(\mathrm{dag} \mathrm{kg}^{-1)}\right.$} \\
\hline$\left(\mathrm{dS} \mathrm{m} \mathrm{m}^{-1}\right)$ & $\mathrm{cmol}_{\mathrm{c}} \mathrm{kg}^{-1}$ & & $\%$ & Sand & Silt & Clay & $33.42 \mathrm{kPa}^{1}$ & $1519.5 \mathrm{kPa}$ \\
\hline 2.15 & 22.33 & 0.67 & 7.34 & 572.7 & 100.7 & 326.6 & 25.91 & 12.96 \\
\hline
\end{tabular}

$\mathrm{pH}$ - hydrogen potential, OM - Organic matter: Walkley-Black Wet Digestion; $\mathrm{Ca}^{2+}$ and $\mathrm{Mg}^{2+}$ extracted with $1 \mathrm{M} \mathrm{KCl}$ at $\mathrm{pH} 7.0 ; \mathrm{Na}^{+}$ and $\mathrm{K}^{+}$extracted using $1 \mathrm{M} \mathrm{NH}_{4} \mathrm{OAc}$ at $\mathrm{pH} 7.0 ; \mathrm{Al}^{3+}+\mathrm{H}^{+}$extracted using 0,5 M CaOAc $\mathrm{pH}$ 7.0; ECse - electrical conductivity of the saturation extract; CEC - Cation exchange capacity; SAR - Sodium adsorption ratio - $\left(\mathrm{mmol} \mathrm{L}^{-1}\right)^{0,5}$; ESP - Exchangeable sodium percentage.

Before seedlings were transplanted, the soil was brought to field capacity using the respective irrigation water of each treatment. After transplantation, irrigation was daily performed and each lysimeter received a water volume to maintain the soil close to field capacity. The irrigation with respective water, was performed daily, and the water volume to be applied to the plants was determined using Eq. 1:

$V I=\frac{(V a-V d)}{1-L F} \ldots \ldots \ldots \ldots \ldots \ldots \ldots \ldots \ldots \ldots \ldots \ldots \ldots \ldots$

Where: $\mathrm{VI}=$ volume of water to be used in the next irrigation event $(\mathrm{mL}) ; \mathrm{Va}=$ volume applied in the previous irrigation event $(\mathrm{mL}) ; \mathrm{Vd}$ volume drained $(\mathrm{mL})$, and $\mathrm{LF}=$ leaching fraction of 0.1 $(10 \%)$

Fertilization with phosphorus and nitrogen was performed as recommended by Musser (1955), applying the equivalent to 250 and $53 \mathrm{~g}$ per plant of single superphosphate and urea, respectively. Phosphorus was entirely applied at planting, whereas nitrogen and potassium, according to the dose, were split into 12 equal monthly applications. To meet probable deficiencies of micronutrients, a Ubyfol solution containing $1.5 \mathrm{~g} \mathrm{~L}^{-1}$ [(N (15\%); $\mathrm{P}_{2} \mathrm{O}_{5}$ (15\%); $\mathrm{K}_{2} \mathrm{O}$ (15\%); $\mathrm{Ca}(1 \%) ; \mathrm{Mg}(1.4 \%) ; \mathrm{S}$ (2.7\%); Zn (0.5\%); B (0.05\%); Fe (0.5\%); $\mathrm{Mn}$ $(0.05 \%) ; \mathrm{Cu}(0.5 \%) ; \mathrm{Mo}(0.02 \%)]$ was weekly applied on West Indian cherry plants.

Contents of chlorophyll a (Chl $a)$, chlorophyll $b$ (Chl $b$ ), carotenoids (Car), leaf osmotic potential $(\psi s)$, water saturation deficit (WSD) and percentage of cell membrane damage (\%D) were evaluated at 340 days after transplanting
(DAT), whereas the relative growth rates in diameter of the rootstock (RGRdr), grafting point (RGRdg) and scion (RGRds) were evaluated from 30 to 340 DAT.

To determine leaf osmotic potential, leaves from the middle third part of the plants were collected in each experimental plot, placed in plastic bags and stored at temperature of $5{ }^{\circ} \mathrm{C}$. To extract cell sap, the samples were placed in tubes for centrifugation at $10,000 \mathrm{rpm}$ for 10 minutes. The freezing point of the samples was measured by reading 5-mL aliquots in an osmometer (PZL 1000), thus finding sample osmolality in $\mathrm{mOsm} \mathrm{kg}^{-1} \mathrm{H}_{2} \mathrm{O}$, converted to $\mathrm{MPa}$, as recommended by Bagatta et al. (2008), through Eq.2:

$\psi=-C \times 2.58 \times 10^{-3}$

Where: $\psi \mathrm{s}=$ leaf osmotic potential - MPa; $\mathrm{C}=$ sample osmolality $-\mathrm{mOsm} \mathrm{\textrm {kg } ^ { - 1 }} \mathrm{H}_{2} \mathrm{O}$, obtained in the osmometer reading.

Percentage of cell membrane damage was determined to evaluate cell membrane disruption capacity under saline stress conditions. Four 113$\mathrm{mm}^{2}$ leaf discs were collected also in the middle third part of the plants, washed in distilled water to remove electrolytes adhered to the leaves and placed in beakers containing $50 \mathrm{~mL}$ of double-distilled water, hermetically sealed with aluminum foil. The samples remained at temperature of $25^{\circ} \mathrm{C}$ for 120 minutes, and the initial electrical conductivity (Ci) was measured. The beakers were then taken to a forced-air oven and subjected to temperature of 80 ${ }^{\circ} \mathrm{C}$ for 150 minutes, and the final electrical conductivity (Cf) was measured. Thus, percentage 
of cell membrane damage was obtained according to Scotti-Campos et al. (2013), using Eq .3:

$\% \mathrm{D}=\frac{\mathrm{Ci}}{\mathrm{cf}} \times 100 \ldots$

Where: $\% \mathrm{D}=$ percentage of cell membrane damage (\%); $\mathrm{Ci}=$ initial electrical conductivity (dS $\left.\mathrm{m}^{-1}\right) ; \mathrm{Cf}=$ final electrical conductivity $\left(\mathrm{dS} \mathrm{m} \mathrm{m}^{-1}\right)$;

Water deficit saturation was determined 340 DAT, following the methodology described by Taiz \& Zeiger (2013), according to Eq. 4:

$$
\text { WSD }=\frac{\text { TW }- \text { FW }}{\text { TW }- \text { DW }} \times 100
$$

Where: WSD = water saturation deficit $(\%)$; $\mathrm{FW}=$ leaf fresh weight $(\mathrm{g})$; $\mathrm{TW}=$ leaf turgid weight (g); DW = leaf dry weight (g).

Contents of chlorophylls $a$ (Chl $a$ ) and $b$ $(\mathrm{Chl} b)$ and carotenoids were evaluated following the laboratory method developed by Arnon (1949), using samples of 5 discs from the blade of the third mature leaf from the apex of the fourth-order branch. The $80 \%$ acetone extracts were used to determine the contents of chlorophylls and carotenoids in the solutions using a spectrophotometer at the absorbance (ABS) wavelengths of 470, 646, and $663 \mathrm{~nm}$, through the following equations: Chlorophyll $a(\mathrm{Chl} a)=12.21$ ABS663 - 2.81 ABS646; Chlorophyll $b(\mathrm{Chl} b)=$ 20.13 A646 - 5.03 ABS663; Total carotenoids $($ Car $)=(1000$ ABS470 - 1.82 Chl $a-85.02 \mathrm{Chl}$ $b) / 198$. The values obtained for the contents of chlorophyll $a, b$ and carotenoids in the leaves were expressed in $\mathrm{mg} \mathrm{g}^{-1}$ of fresh matter (FM).
The RGR in diameters of rootstock, at grafting point and scion were determined according to Benincasa (2003), through Eq. 4.

$\mathrm{RGR}=\frac{(\operatorname{InSD} 2-\operatorname{InSD} 1)}{(\mathrm{t} 2-\mathrm{t} 1)}$

Where: $\mathrm{RGR}=$ Relative growth rate in stem diameter $\left(\mathrm{mm} \mathrm{mm}^{-1} \mathrm{~d}^{-1}\right)$,

$\mathrm{SD}_{1}=$ stem diameter $(\mathrm{mm})$ at time $\mathrm{t}_{1}$,

$\mathrm{SD}_{2}=$ stem diameter $(\mathrm{mm})$ at time $\mathrm{t}_{2}$,

ln = natural logarithm.

The data were subjected to analysis of variance by $F$ test and, when significant, means comparison test (Tukey test at 0.05 probability level) was conducted for water salinity levels and regression analysis was carried out for $\mathrm{K}$ doses. When the interaction between factors (LS x KD) was significant (Tukey test at 0.05 probability level), a follow-up analysis was performed for saline levels in each $\mathrm{K}$ dose, using the statistical program SISVAR-ESAL (FERREIRA, 2011).

\section{RESULTS AND DISCUSSON}

The summary of the analysis of variance (Table 2) showed significant effect of the interaction between salinity levels and $\mathrm{K}$ doses (SL $\mathrm{x}$ KD) on the percentage of cell membrane damage $(\% \mathrm{D})(\mathrm{p}<$ 0.01 ). For the isolated factors, water salinity levels had significant effect on leaf osmotic potential $(\psi s)$, whereas $\mathrm{K}$ doses had significant effect on water saturation deficit in West Indian cherry leaves, at 340.DAT.

Table 2. Summary of the analysis of variance for leaf osmotic potential ( $\psi s)$, percentage of cell membrane damage (\%D) and water saturation deficit (WSD) in grafted West Indian cherry irrigated with saline water and fertilized with different doses of potassium, at 340 days after transplanting.

\begin{tabular}{lllll}
\hline \multirow{2}{*}{ Source of variation } & \multirow{2}{*}{$\mathrm{DF}$} & \multicolumn{2}{l}{ Mean squares } \\
\cline { 3 - 5 } & & $\Psi \mathrm{S}$ & $\% \mathrm{D}$ & WSD \\
\hline Saline levels (SL) & 1 & $0.3106^{* *}$ & $7.4416^{* * *}$ & $8.6025^{\mathrm{ns}}$ \\
K dose (KD) & 3 & $0.0774^{\mathrm{ns}}$ & $76.415^{* *}$ & $18.103^{*}$ \\
$\quad$ Linear regression & 1 & $0.0524^{\mathrm{ns}}$ & $127.67^{* *}$ & $5.4890^{*}$ \\
Quadratic regression & 1 & $0.0092^{\mathrm{na}}$ & $122.236^{* *}$ & $11.578^{*}$ \\
Interaction (SL x KD) & 3 & $0.0524^{\mathrm{ns}}$ & $17.387^{* *}$ & $44.507^{\mathrm{ns}}$ \\
Blocks & 2 & $0.0092^{\mathrm{ns}}$ & $0.1762^{\mathrm{ns}}$ & $0.0075^{\mathrm{ns}}$ \\
Residual & 14 & 0.0090 & 0.5732 & 3.5128 \\
\hline $\mathrm{CV}(\%)$ & 4.23 & 4.57 & 3.51 \\
\hline ns, $* *, *$ respectively not significant, significant at $\mathrm{p}<0.01$ and $\mathrm{p}<0.05$.
\end{tabular}

According to the comparison test of means for leaf osmotic potential (Figure 1A), West Indian cherry plants irrigated with water of $0.8 \mathrm{dS} \mathrm{m}^{-1}$ electrical conductivity significantly differed from those subjected to the higher salinity $\left(3.8 \mathrm{dS} \mathrm{m} \mathrm{m}^{-1}\right)$. Comparing the means between treatments, plants under ECw of $0.8 \mathrm{dS} \mathrm{m}^{-1}$ showed the higher osmotic potential in leaf tissues (-1.30 MPa), whereas plants receiving high-salinity water showed the lowest $\psi \mathrm{s}$ $(-1.60 \mathrm{MPa})$. Likewise, the reduction in the energy status of the water in plant leaf tissues, due to the decrease in $\psi \mathrm{s}$ of West Indian cherry plants grown under the highest $\mathrm{ECw}$ level, may be associated with a strategy of acclimation to the increment in 
the salt concentration of the soil solution, allowing for plant tissue hydration and thus delaying deleterious processes caused by water deficit due to the increase in the osmotic concentration of the soil solution (SANTOS et al., 2012). Reduction in leaf osmotic potential due to saline water irrigation has also been observed in other crops, such as jatropha (SILVA et al., 2009), peanut (SANTOS et al., 2012) and castor bean (LIMA et al., 2015).
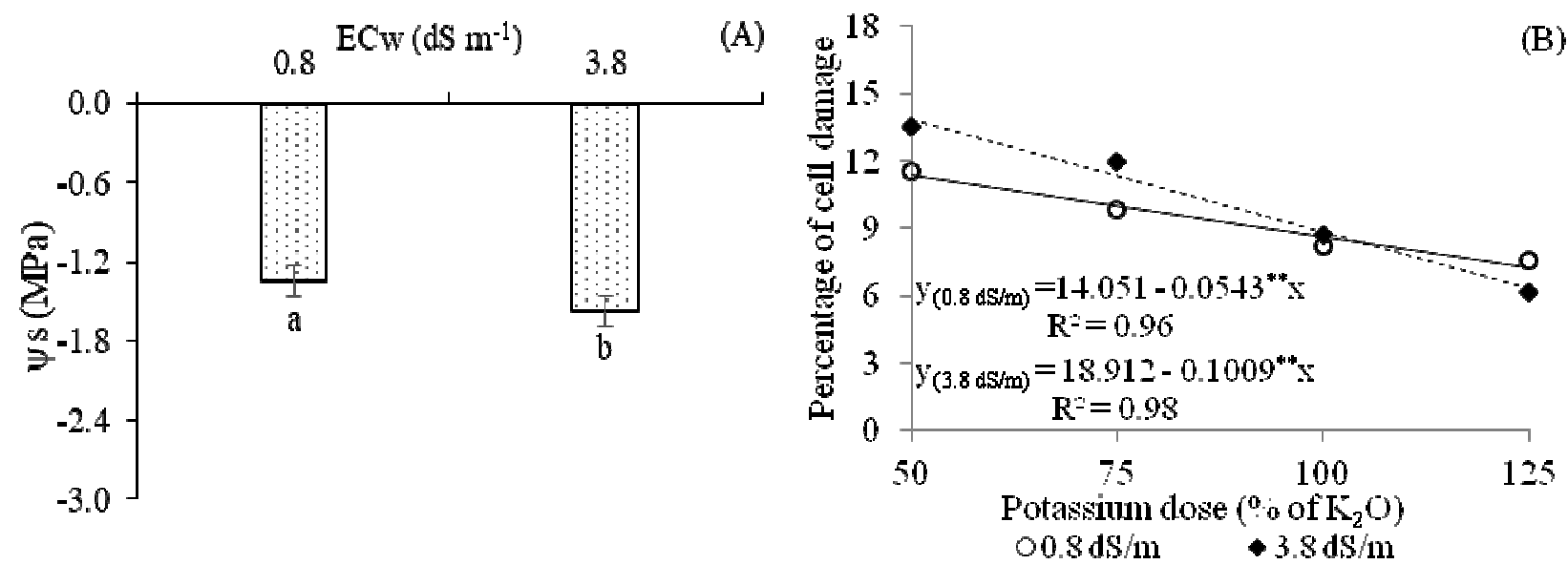

Figure 1. Osmotic potential - $\psi \mathrm{s}(\mathrm{A})$, under different irrigation water salinity - ECw (A) and percentage of cell membrane damage (B) as a function of the interaction between water salinity (ECw) and potassium dose in grafted West Indian cherry plants, at 340 days after transplanting.

Based on the regression equations for percentage of cell membrane damage - \%D (Figure 1B), plants under ECw of 0.8 and $3.8 \mathrm{dS} \mathrm{m}^{-1}$ fitted to a linear model, and $\% \mathrm{D}$ decreased in plants subjected to $0.8 \mathrm{dS} \mathrm{m}^{-1}$ as $\mathrm{K}$ dose increased, with reduction of $9.66 \%$ for every $25 \%$ increase in $\mathrm{K}_{2} \mathrm{O}$ doses. In other words, plants fertilized with the highest $\mathrm{K}$ dose $\left(125 \% \mathrm{~K}_{2} \mathrm{O}\right)$ showed reduction in $\% \mathrm{D}$ of approximately $4.07 \%$ in comparison to those receiving $50 \%$ of the $\mathrm{K}_{2} \mathrm{O}$ recommendation. West Indian cherry plants irrigated with $3.8 \mathrm{dS} \mathrm{m}^{-1}$ water also showed reduction in the $\% \mathrm{D}, 13.33 \%$ for every $25 \%$ increase in $\mathrm{K}_{2} \mathrm{O}$ recommendation, which is equivalent to a reduction of about $48 \%$ in the $\% \mathrm{D}$ of West Indian cherry plants fertilized with $125 \% \mathrm{~K}_{2} \mathrm{O}$ dose, compared with those under $50 \%$ of the recommendation of Musser (1995). Cell membrane damage is caused by the release of ions, leading to greater loss in integrity and destabilization of the cell membrane, and the quantity of leachates is determined considering that the higher the content leaked from the cell, the greater the damage caused to the cell membrane (ATAÍDE, 2012), which may indicate a mechanism that prevents tissue desiccation due to the reduction in the leaf osmotic component (FIOREZE et al., 2013).

Water saturation deficit (WSD) in West Indian cherry plants fitted to a quadratic model as a function of the $\mathrm{K}_{2} \mathrm{O}$ doses and, according to the regression equation (Figure 2), WSD increased up to the $74 \%$ with $\mathrm{K}_{2} \mathrm{O}$ dose $(64.15 \%)$. From this dose on, WSD decreased and its lowest value $(59.93 \%)$ occurred in plants fertilized with $125 \% \quad \mathrm{~K}_{2} \mathrm{O}$ recommendation. The reduction in the WSD of West Indian cherry plants is mainly due to the functions performed by $\mathrm{K}$ in plant metabolism, since this macronutrient participates in the maintenance of ionic balance and cell turgor, through the control of stomatal opening and closure (GURGEL et al., 2010).

Sá et al. (2017), evaluating the effects of irrigation with different water salinity levels $(\mathrm{ECW}$ between 0.6 and $3.8 \mathrm{dS} \mathrm{m}^{-1}$ ) and fertilization with different proportions of nitrogen and phosphorus $(100: 100,100: 140,140: 100$ and140:140\% of the recommended doses of $\mathrm{N}$ and $\mathrm{P}$ ) on the water relations of the same cultivar at 45 days after transplanting, observed reduction of water saturation deficit in the leaves, regardless of the irrigation water salinity levels.

Based on the summary of analysis of variance (Table 3 ), the interaction between factors (SL $x \quad$ KD) significantly influenced $(\mathrm{p}<0.01)$ chlorophyll $b$ content $(\mathrm{Chl} b)$. The factor salinity levels caused significant differences in chlorophyll $a$ content $(\mathrm{Chl} a)$, relative growth rate in stem diameter at the grafting point and in the scion. Potassium doses caused significant effect only on the contents of chlorophyll $a(\mathrm{Chl} a)$, chlorophyll $b$ (Chl $b$ ) and carotenoids (Car). 


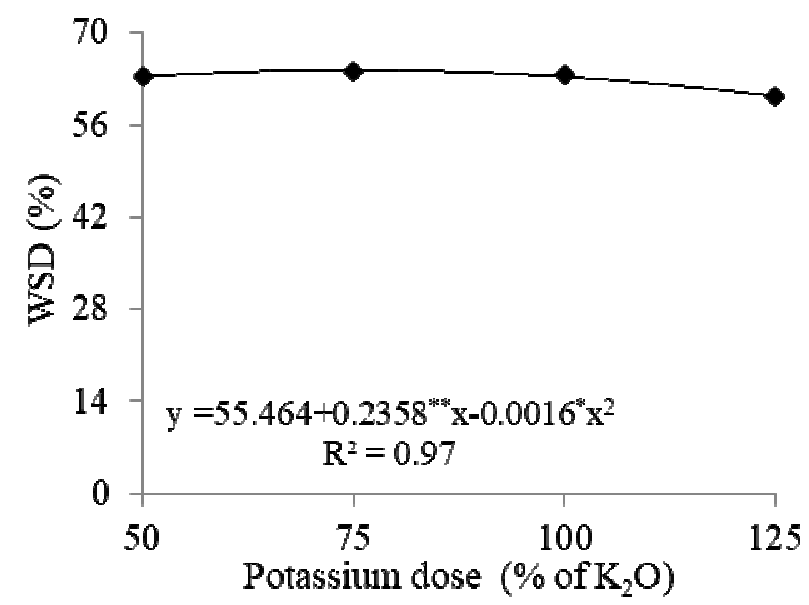

Figure 2. Water saturation deficit - WSD in the leaves of grafted West Indian cherry, as a function of potassium dose, at 340 days after transplanting.

Table 3. Summary of the analysis of variance for the contents of chlorophyll $a$ (Chl $a$ ), chlorophyll $b$ (Chl $b$ ) and carotenoids (Car), at 340 days after transplanting (DAT), and relative growth rate in stem diameter for rootstock (RGRdr), grafting point (RGRdg) and scion (RGRds) of grafted West Indian cherry irrigated with different water salinity levels and potassium doses, from 30 to 340 DAT.

\begin{tabular}{llllllll}
\hline \multirow{2}{*}{ Source of variation } & \multirow{2}{*}{ DF } & \multicolumn{6}{l}{ Mean squares } \\
\cline { 3 - 7 } & & Chl $a$ & Chl $b$ & Car & RGRdr & RGRdg & RGRds \\
\hline Saline levels (SL) & 1 & $0.3209^{*}$ & $0.0105^{\text {ns }}$ & $0.0153^{\text {ns }}$ & $7.6964^{\text {ns }}$ & $0.000002^{* *}$ & $0.000003^{* *}$ \\
K doses (KD) & 3 & $0.2502^{*}$ & $0.0356^{* *}$ & $0.0453^{*}$ & $1.6681^{\text {ns }}$ & $5.146677^{\text {ns }}$ & $1.481111^{\text {ns }}$ \\
Linear regression & 1 & $0.1410^{\text {ns }}$ & $0.0153^{*}$ & $16.078^{* *}$ & $0.0001^{\text {ns }}$ & $0.000001^{\text {ns }}$ & $0.000001^{\text {ns }}$ \\
Quadratic regression & 1 & $0.2015^{*}$ & $0.0453^{* *}$ & $0.6221^{\text {ns }}$ & $0.0001^{\text {ns }}$ & $0.000001^{\text {ns }}$ & $0.000001^{\text {ns }}$ \\
Interaction (SL x KD) & 3 & $0.0535^{\text {ns }}$ & $0.0376^{* *}$ & $2.2095^{\text {ns }}$ & $7.7184^{\text {ns }}$ & $8.901965^{\text {ns }}$ & $1.350627^{\text {ns }}$ \\
Blocks & 2 & $0.0774^{\text {ns }}$ & $0.0102^{\text {ns }}$ & $2.3795^{\text {ns }}$ & $2.9059^{\text {ns }}$ & $6.725634^{\text {ns }}$ & $5.135481^{\text {ns }}$ \\
Residual & 14 & 0.0471 & 0.0043 & 1.4312 & 4.4726 & 1.3054 & 2.3343 \\
\hline CV $(\%)$ & & 3.40 & 4.33 & 2.43 & 4.47 & 4.30 & 3.33 \\
\hline
\end{tabular}

ns, $* *, *$ respectively not significant, significant at $\mathrm{p}<0.01$ and $\mathrm{p}<0.05$.

Chlorophyll a content $(C h l a)$ in West Indian cherry plants was significantly influenced by the increment in irrigation water salinity and, according to the means comparison test (Figure 3A), the $C h l a$ in plants under ECw of $0.8 \mathrm{dS} \mathrm{m}^{-1}$ was statistically lower than that of plants irrigated with $3.8 \mathrm{dS} \mathrm{m}^{-1}$ water. Chlorophyll $a$ contents of 1.71 and $1.94 \mathrm{mg} \mathrm{g}^{-1} \mathrm{FM}$ were found in plants under 0.8 and $3.8 \mathrm{dS} \mathrm{m}^{-1}$, respectively. Chlorophyll is one of the main factors related to plant photosynthetic efficiency and, consequently, to growth and adaptability to different environments and adverse conditions caused by the various types of stress (AMARANTE et al., 2007). Therefore, increase in chlorophyll synthesis, due to irrigation with saline water $\left(3.8 \mathrm{dS} \mathrm{m}^{-1}\right)$, may be associated with the activation of a mechanism of protection of the photosynthetic apparatus, and is apparently a direct result of the development of chloroplasts, by the increase in the number of thylakoids or even increase in the number of chloroplasts (SILVA et al., 2016).

Potassium application in increasing doses positively influenced the chlorophyll $a$ content of West Indian cherry and, according to the regression equation (Figure 3B), the data fitted to an positive linear model, with increment of $7.12 \%$ for every $25 \%$ increase in $\mathrm{K}_{2} \mathrm{O}$ dose. In other words, when plants were fertilized with the dose of $125 \% \mathrm{~K}_{2} \mathrm{O}$ recommendation, $\mathrm{Chl}$ a content increased by 0.30 $\mathrm{mg} \mathrm{g}^{-1}$ FM compared with plants receiving 50\% $\mathrm{K}_{2} \mathrm{O}$ recommendation. Therefore, the increase in chlorophyll contents may be related to the physiological functions of this macronutrient, since $\mathrm{K}$ participates in the beginning of the metabolic processes of $\mathrm{N}$, such as incorporation of mineral $\mathrm{N}$ and especially in nitrate reductase (RUAN; HARDTER, 1999), a key enzyme in the regulation of $\mathrm{N}$ metabolism (VIANA; KIEHL, 2010). Thus, $\mathrm{K}_{2} \mathrm{O}$ may have favored protein synthesis and chlorophyll formation in West Indian cherry plants, 
because $\mathrm{N}$ is used in the synthesis of cell compounds.
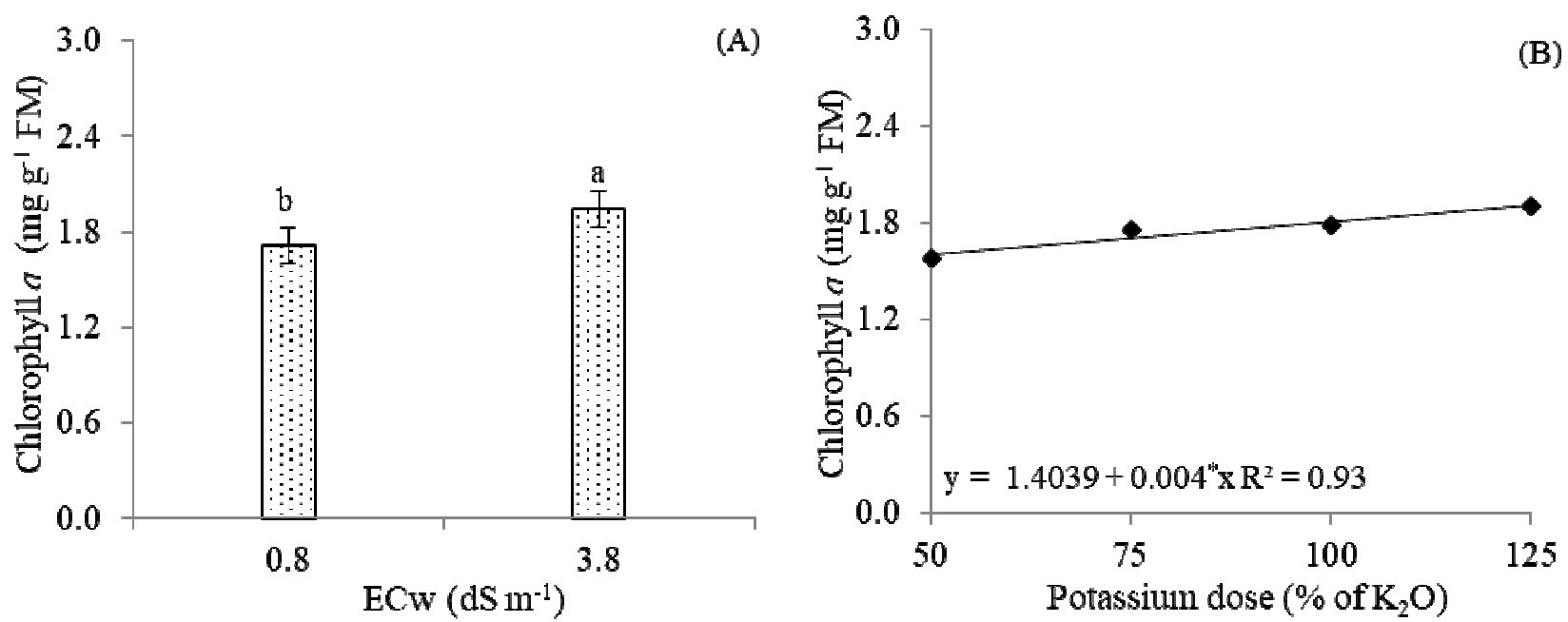

Bars represent the standard error of the mean $(n=3)$. Means followed by different letters indicate difference between treatments by Tukey test, $\mathrm{p}<0.05$.

Figure 3. Chlorophyll $a$ content $(\mathrm{Chl} a)$ in grafted West Indian cherry, as a function of irrigation water salinity - ECw (A) and potassium fertilization (B), at 340 days after transplanting.

The interaction between irrigation water salinity and $\mathrm{K}$ doses also influenced the chlorophyll $b$ content $(C h l b)$ of West Indian cherry. According to the regression equations (Figure 4A), plants receiving water of $0.8 \mathrm{dS} \mathrm{m}^{-1}$ electrical conductivity obtained maximum estimated value of $0.84 \mathrm{mg} \mathrm{g}^{-1}$ $\mathrm{FM}$ at dose of $116 \% \mathrm{~K}_{2} \mathrm{O}$ recommendation and, from this point on, there was a slight reduction in the chlorophyll $b$ content. When the plants were irrigated with $3.8 \mathrm{dS} \mathrm{m}^{-1}$ water, the data fitted to the regression model as $\mathrm{K}$ doses increased and, from the dose of $71 \%\left(0.699 \mathrm{mg} \mathrm{g}^{-1} \mathrm{FM}\right)$, plants irrigated with water of highest electrical conductivity showed a sharp reduction in the chlorophyll $b$ contents.
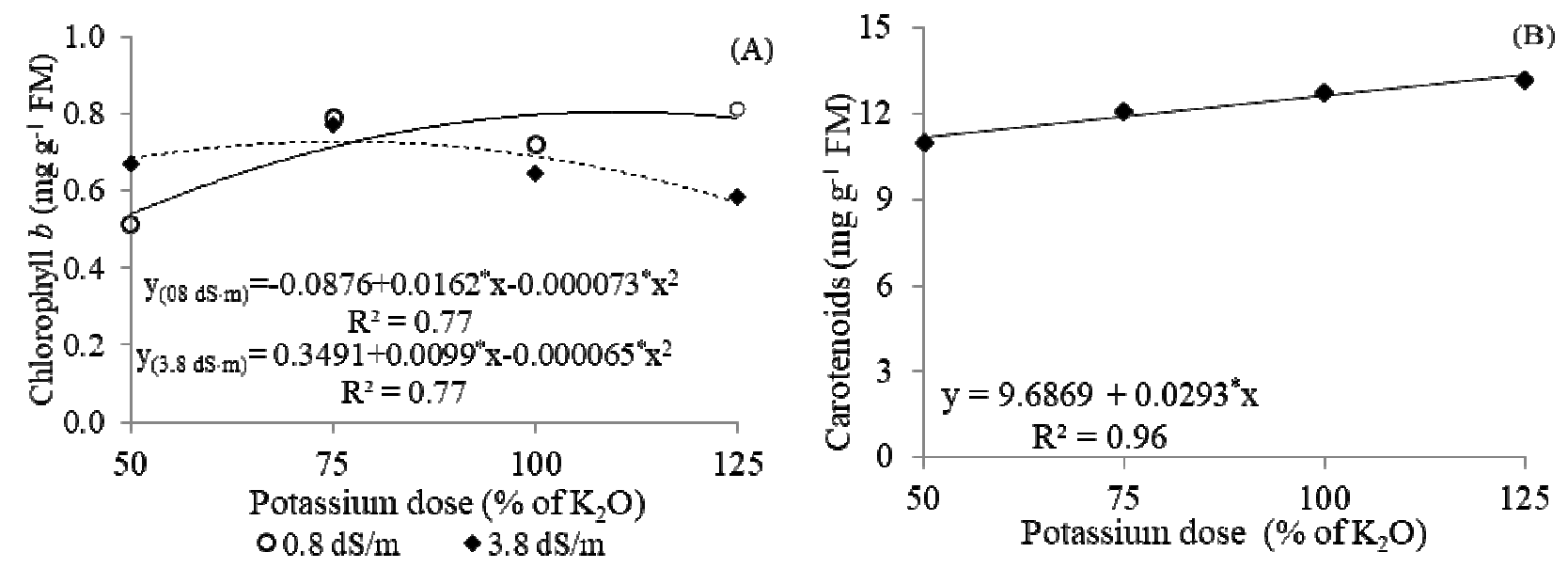

Figure 4. Chlorophyll $b$ content as a function of the interaction between water salinity levels - ECw and potassium doses (A) and carotenoids content as a function of potassium doses (B), of West Indian cherry at 340 days after transplanting.

According to Larré et al. (2014), the enzyme chlorophyllase is stimulated in the first days of exposure to stress (moderate stress), but this activity is strongly inhibited by high salt concentration. Nevertheless, it can be inferred that $\mathrm{K}$ fertilization positively influences chlorophyll index, if adequate amount is provided, because besides increasing $\mathrm{N}$ assimilation and transport, $\mathrm{K}$ is responsible for the movement of the stomatal guard cells, regulating the entry of $\mathrm{CO}_{2}$, which serves as fuel for photosynthesis, as reported by Appezzato-da-Glória \& Carmello-Guerreiro (2012).

The content of carotenoids in West Indian cherry plants increased significantly as $\mathrm{K}_{2} \mathrm{O}$ doses 
increased and, according to the regression equation (Figure 4B), there was an increment of $7.56 \%$ for every $25 \%$ increase in $\mathrm{K}$ doses. Carotenoids content increased by $2.2 \mathrm{mg} \mathrm{g}^{-1} \mathrm{FM}$ between plants fertilized with $125 \%$ and $50 \% \quad \mathrm{~K}_{2} \mathrm{O}$ recommendation. The increase in carotenoids content in the leaves may be attributed to a strategy in an attempt to minimize the damages to the photosynthetic apparatus. In addition, carotenoids are considered as accessory pigments, because the light absorbed by them is transferred to the chlorophyll for photosynthesis (TAIZ \& ZEIGER, 2013).

The relative growth rate of stem diameter at the grafting point of West Indian cherry plants was significantly influenced by the irrigation with different water salinity levels. According to the means comparison test (Figure $5 \mathrm{~A}$ and $\mathrm{B}$ ), the RGRdr and RGRds of plants irrigated with $0.8 \mathrm{dS}$ $\mathrm{m}^{-1}$ water was significantly higher than the values found in plants subjected to the highest water salinity level $\left(3.8 \mathrm{dS} \mathrm{m}^{-1}\right)$, the plants subjected to 3.8 $\mathrm{dS} \mathrm{m}{ }^{-1}$ salinity showed reductions in RGRdr and RGRds of 11.30 and $18.06 \%$, equivalent to growth reductions of 0.00056 and $0.00069 \mathrm{~mm} \mathrm{~mm}^{-1}$ day $^{-1}$, respectively, in comparison to plants under $\mathrm{ECw}$ of $0.8 \mathrm{dSm}^{-1}$.
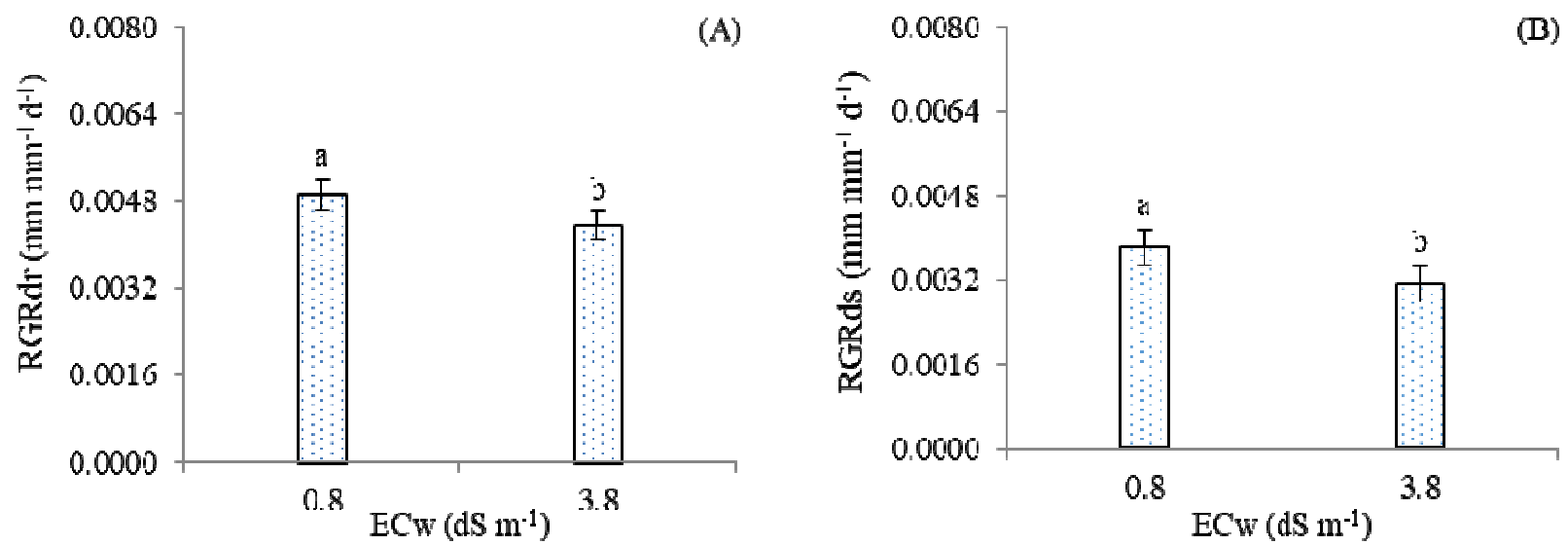

Bars represent the standard error of the mean $(n=3)$. Means followed by different letters indicate difference between treatments by Tukey test, $\mathrm{p}<0.05$.

Figure 5. Relative growth rate of stem diameter at the grafting point - RGRdr (A) and scion - RGRds (B) of West Indian cherry plant under different irrigation water salinity - ECw, from 30 to 340 days after transplanting.

The reduction in growth rate is caused by soil salinity. As plants are irrigated with saline water, the salt content in the soil increases and exceeds the tolerable limit, and the growth rate of most species progressively decreases, given the difficulty to absorb water due to the reduction in the osmotic potential of the soil solution (GURGEL et al., 2003). Sá et al. (2018), studying the growth of the West Indian cherry cv. 'BRS 366 Jaburu' under saline conditions (ECw: 0.6 to $3.8 \mathrm{dS} \mathrm{m}^{-1}$ ), observed reduction in the absolute and relative growth rates for the rootstock and scion as a function of water salinity from 1 to 150 days after transplanting.

\section{CONCLUSIONS}

The West Indian cherry crop is sensitive to water salinity of $3.8 \mathrm{dS} \mathrm{m}^{-1}$ in the post-grafting phase, resulting in a decline in photosynthetic pigment content and growth.
Increase in potassium dose reduces cell membrane damage and promotes increment in the synthesis of chlorophyll $a$ and carotenoids in West Indian cherry plants.

A significant interaction exists between water salinity levels and potassium doses for the water saturation deficit, percentage of cell membrane damage and chlorophyll $b$ content of West Indian cherry plants.

\section{ACKNOWLEDGMENTS}

To the National Council for Scientific and Technological Development (CNPq/UFCG) and to the National Postdoctoral Program (PNPD/CAPES/UFCG), for grant of scholarship, and to the National Institute of Science and Technology in Salinity - INCTSal, for funding the project. 
RESUMO: A exploração agrícola na região semiárida do Nordeste brasileiro depende do uso da irrigação para garantir a produção das culturas com segurança; entretanto, nesta região, as águas utilizadas comumente possuem níveis elevados de sais e necessitam de estratégias de manejo que possibilitem sua utilização na agricultura. Neste contexto, objetivou-se com este trabalho avaliar as relações hídricas, os pigmentos fotossintéticos e o crescimento da aceroleira enxertada em função da irrigação com águas salinas e adubação potássica. A pesquisa foi realizada em condição de casa de vegetação em lisímetros preenchidos com um Neossolo Regolítico Eutrófico de textura franco-arenosa, no município de Campina Grande-PB. Os tratamentos foram distribuídos em blocos casualizados, e consistiram de dois fatores, sendo dois níveis de condutividade elétrica da água de irrigação - $\mathrm{CEa}\left(0,8\right.$ e $\left.3,8 \mathrm{dS} \mathrm{m}^{-1}\right)$ e quatro doses de potássio $(50,75 ; 100$ e $125 \%$ da recomendação), com três repetições e uma planta por parcela. A dose de $100 \%$ correspondeu a 33,0 g de $\mathrm{K}_{2} \mathrm{O}$ por planta por ano. A cultura da aceroleira é sensível a salinidade da água de $3,8 \mathrm{dS} \mathrm{m}^{-1}$, na fase pós enxertia, resultando-se em declínio nos teores de pigmentos fotossintéticos e crescimento. Doses crescentes de potássio diminuíram o percentual de dano na membrana celular e promoveram aumento na síntese de clorofila $a$ e carotenoides nas plantas de aceroleira. Houve interação significativa entre os fatores níveis salinos e doses de potássio para potencial osmótico foliar, déficit de saturação hídrica, percentual de dano na membrana celular e teor de clorofila $b$ da aceroleira.

PALAVRAS-CHAVE: Malphigia emarginata. Estresse salino. Osmorregulação.

\section{REFERENCES}

ADRIANO, E.; LEONEL, S.; EVANGELISTA, R. M. Qualidade de fruto da aceroleira cv. Olivier em dois estádios de maturação. Revista Brasileira Fruticultura, Jaboticabal, v. 33, n. 1, p. 541-545, 2011. http://dx.doi.org/10.1590/S0100-29452011000500073.

AMARANTE, L. do; OLIVEIRA, C. D. S.; ZENZEN, M. L.; BERNARDI, E. Teores de clorofilas em soja associada simbioticamente com diferentes estirpes de brady rhizobium sob alagamento. Revista Brasileira de Biociências, Porto Alegre, v. 5, n. 2, p. 906-908, 2007

APPEZZATO-da-GLÓRIA, B.; CARMELLO-GUERREIRO, S. M. Anatomia vegetal. 3. ed. rev. e ampl, Viçosa: Ed. UFV, 2012. 404p.

ARNON, D. I. Copper enzymes in isolated cloroplasts: polyphenoloxidases in Beta vulgaris. Plant Physiology, Waterbury, v. 24, n. 1, p. 1-15, 1949. https://doi.org/10.1104/pp.24.1.1

ATAÍDE, G. M.; FLORES, A. V.; BORGES, E. E. L. Alterações fisiológicas e bioquímicas em sementes de Pterogyne nitens Tull. durante o envelhecimento artificial. Pesquisa Agropecuária Tropical, Goiânia, v. 42, n. 1, p. 71-76, 2012. http://dx.doi.org/10.1590/S1983-40632012000100010.

BAGATTA, M.; PACIFICO, D.; MANDOLINO, G. Evaluation of the osmotic adjustment response within the Genus Beta. Journal of Sugar Beet Research, Denver, v .45 n. 3, p. 119-131, 2008.

http://dx.doi.org/10.5274/jsbr.45.3.119.

BENINCASA, M. M. P. Análise de crescimento de plantas, noções básicas. 2 ed. Jaboticabal: FUNEP, 2003. $41 \mathrm{p}$.

CABANERO, F. J.; MARTÍNEZ, V.; CARVAJAL, M. Does calcium determine water uptake under saline conditions in pepper plants, or is it water flux which determines calcium uptake? Plant Science, Shannon, v. 166, n.2, p.443-450, 2004. http://dx.doi.org/10.1016/j.plantsci.2003.10.010.

DEMBITSKY, V.; POOVARODOM, S.; LEONTOWICZ, H.; LEONTOWICZ, M.; VEARASILP, S.; TRAKHTENBERG, S.; GORINSTEIN, S. The multiple nutrition properties of some exotic fruits: biological activity and active metabolites. Food Research International, Essex, v.44, n.7, p. 1671-1701, 2011. https://doi.org/10.1016/j.foodres.2011.03.003. 
DONAGEMA, G. K.; CAMPOS, D. V. B de; CALDERANO, S. B.; TEIXEIRA, W. G.; VIANA, J. H. M. (Org.). Manual de métodos de análise de solo. 2. ed. Rio de Janeiro, RJ: Embrapa Solos. 2011. 230 p.

EMBRAPA - Empresa Brasileira de Pesquisa Agropecuária/Agroindústria Tropical. Cultivar acerola BRS 366-Jaburu. Fortaleza: Embrapa CNPAT, 2012. 2p.

ESASHIKA, T.; OLIVEIRA, L. A.; MOREIRA, F, W. Resposta da aceroleira a adubação orgânica, química e foliar num Latossolo da Amazônia Central. Revista de Ciências Agrárias, Lisboa, v.36, n.4, p.399-410, 2013.

FERREIRA, D. F. SISVAR: A computer statistical analysis system. Ciência e Agrotecnologia, Lavras, v. 35, n.6, p. 1039-1042, 2011. http://dx.doi.org/10.1590/S1413-70542011000600001.

\section{FILGUEIRA, F. A. R. Novo manual de olericultura: Agrotecnologia moderna na produção e} comercialização de hortaliças. 3.ed. Viçosa: UFV, 2005. 421 p.

FIOREZE, S. L.; RODRIGUES, J. D.; CARNEIRO, J. P. C.; SILVA, A. do A.; LIMA, M. B. Fisiologia e produção da soja tratada com cinetina e cálcio sob déficit hídrico e sombreamento. Pesquisa Agropecuária Brasileira, Brasília, v.48, n.11, p.1432-1439, 2013. http://dx.doi.org/10.1590/S0100-204X2013001100003.

GURGEL, M. T.; FERNANDES, P. D.; GHEYI, H. R.; SANTOS, F J. DE S.; BEZERRA, I. L.; NOBRE, R. G. Índices fisiológicos e de crescimento de um porta-enxerto de aceroleira sob estresse salino. Revista Brasileira de Engenharia Agrícola e Ambiental, Campina Grande, v.7, n.3, p.451-456, 2003. http://dx.doi.org/10.1590/S1415-43662003000300007.

GURGEL, M. T.; GHEYI, H. R.; OLIVEIRA, F. H. T. Acúmulo de matéria seca e nutrientes em meloeiro produzido sob estresse salino e doses de potássio. Revista Ciência Agronômica, Fortaleza, v. 41, n. 1, p. 1828, 2010. http://dx.doi.org/10.5935/1806-6690.20100003.

GURGEL, M. T.; UYEDA, C. A.; GHEYI, H. R.; OLIVEIRA, F. H. T. de; FERNANDES, P. D.; SILVA, F. V. da. Crescimento de meloeiro sob estresse salino e doses de potássio. Revista Brasileira de Engenharia Agrícola e Ambiental, Campina Grande, v.14, n.1, p.3-10, 2010. http://dx.doi.org/10.1590/S141543662010000100001.

JIANG, J.; LIU, G.; YAO, R.; YU, S. Effect of irrigation amount and water salinity on water consumption and water productivity of spring wheat in Northwest China. Field Crops Research, Amsterdam, v. 137, s.n., p. 78$88,2012$.

LARRÉ, C. F.; MARINI, P.; MORAES, C. L.; AMARANTE, L. do; MORAES, D. M. de. Influência do 24epibrassinolídeo na tolerância ao estresse salino em plântulas de arroz. Semina: Ciências Agrárias, Londrina, v.35, n.1, p.67-76, 2014. http://dx.doi.org/ 10.5433/1679-0359.2014v35n1p67.

LIMA, G. S. de; GHEYI, H. R.; NOBRE, R. G.; SOARES, L. A. dos A.; XAVIER, D. A.; SANTOS JUNIOR, J. A. dos. Water relations and gas exchange in castor bean irrigated with saline water of distinct cationic nature. African Journal of Agricultural Research, Lagos, v.10, n.13, p.1581-1594, 2015. http://dx.doi.org/10.5897/AJAR2015.9606.

MEZADRI, T.; PACHÓN, F.; SOLEDAD, M.; VILLAÑO, D.; PARRÍLLA, G.; CARMEN, M.; TRONCOSO, A. M. El fruto de la acerola: composición, características productivas e importancia económica. Archivos Latinoamericanos de Nutrición, Caracas, v.56, n.2, p.101-109, 2006.

MUSSER, R. S. Tratos culturais na cultura da acerola. In: SÃO JOSÉ, A. R.; ALVES, R. E. (ed.). Acerola no Brasil: produção e mercado. Vitória da Conquista: DFZ/UESB. 1995. p.47-52. 
NAVARRO, J. M.; GARRIDO, C.; MARTÍNEZ, V.; CARVAJAL, M. Water relations and xylem transport of nutrients in pepper plants grown under two different salts stress regimes. Plant Growth Regulation, Dordrecht, v. 41, n.3, p. 237-245, 2003. https://doi.org/10.1023/B:GROW.0000007515.72795.c5

NEVES, A. L. R.; LACERDA, C. F. de; GUIMARÃES, F. V. A.; HERNANDEZ, F. F. F.; SILVA, F. B.; PRISCO, J. T.; GHEYI, H. R. Acumulação de biomassa e extração de nutrientes por plantas de feijão-de-corda irrigadas com água salina em diferentes estádios de desenvolvimento. Ciência Rural, Santa Maria, v.39, n.3, p.758-765, 2009. http://dx.doi.org/10.1590/S0103-84782009005000014.

NOBRE, R. G.; GHEYI, H. R.; SOARES, F. A. L.; CARDOSO, J. A. F. Produção de girassol sob estresse salino e adubação nitrogenada. Revista Brasileira de Ciência do Solo, Viçosa, v.35, n.3, p.929-937, 2011. http://dx.doi.org/10.1590/S0100-06832011000300027.

NOVAIS, R. F.; ALVAREZ, V. H.; BARROS, N. F. de; FONTES, R. L.; CANTARUTTI, R. B.; NEVES, J. C. L. Fertilidade do solo. Viçosa: Sociedade Brasileira de Ciência do Solo, 2007. p.275-374.

RICHARDS, L. A. Diagnosis and improvement of saline and alkali soils. Washington: U. S. Department of Agriculture, 1954. 160p. (USDA, Agriculture Handbook, 60).

ROMHELD, V. Efeitos do potássio nos processos da rizosfera e na resistência das plantas às doenças. In: YAMADA, T.; ROBERTS, T. L. (ed.). Potássio na agricultura brasileira. Piracicaba, 2005. p.301-319.

RUAN, J.; WU, X.; HARDTER, R. Effects of potassium and magnesium nutrition on the quality components of different types of tea. Journal of the Science of Food and Agriculture, New York, v.79, n.1, p.47-52, 1999. https://doi.org/10.1002/(SICI)1097-0010(199901)79:1<47::AID-JSFA172>3.0.CO;2-A

SÁ, F. V. da S.; GHEYI, H. R.; LIMA, G. S. de; PAIVA, E. P. de; FERNANDES, P. D.; MOREIRA, R. C. L.; SILVA, L. de A.; FERREIRA NETO, M. Water relations and gas exchanges of West Indian cherry under salt stress and nitrogen and phosphorus doses. Journal of Agricultural Science, Toronto, v.9, n.10; p.168-177, 2017. https://doi.org/10.5539/ jas.v9n10p168.

SÁ, F. V. da S.; GHEYI, H. R.; LIMA, G. S. de; PAIVA, E. P. de; MOREIRA, R. C. L.; SILVA, L. de A. Water salinity, nitrogen and phosphorus on photochemical efficiency and growth of the West Indian cherry (Malphigia emarginata). Revista Brasileira de Engenharia Agrícola e Ambiental, Campina Grande, v.22, n.3, p. 158-163, 2018. https://doi.org/10.1590/1807-1929/agriambi.v22n3p158-163

SÁ, F. V. S.; LIMA, G. S.; OLIVEIRA, L. D.; GHEYI, H. R.; SOARES, L. A. A.; PAIVA, E. P.; DIAS, A. S. Salt stress, nitrogen and potassium fertilization on growth and fiber quality of colored cotton. International Journal of Current Research, Lucknow, v.8, n.8, p. 36796-36801, 2016.

SANTOS, D. B. DOS; FERREIRA, P. A.; OLIVEIRA, F. G. DE; BATISTA, R. O.; COSTA, A. C.; CANO, M. A. O. Produção e parâmetros fisiológicos do amendoim em função do estresse salino. Idesia, Arica, v.30, n.2, p.69-74, 2012. http://dx.doi.org/10.4067/S0718-34292012000200009.

SCOTTI-CAMPOS, P; PHAM-THI, ANH-THU; SEMEDO, J. N.; PAIS, I. P.; RAMALHO,J. C.; MATOS, M. C. Physiological responses and membrane integrity in three Vigna genotypes with contrasting drought tolerance. Emirates Journal of Food and Agriculture, Abu Dhabi, v.25, n.12, p.1002-1013, 2013. http://dx.doi.org/ 10.9755/ejfa.v25i12.16733.

SILVA, A. R. A. da; BEZERRA, F. M. L.; LACERDA, C. F.de; SOUSA, C. H. C.de; CHAGAS, K. L. Pigmentos fotossintéticos e potencial hídrico foliar em plantas jovens de coqueiro sob estresses hídrico e salino. Revista Agro@mbiente, Boa Vista, v.10, n.4, p.317-325, 2016. http://dx.doi.org/ 10.18227/19828470ragro.v10i4.3650. 
SILVA, E. N.; RIBEIRO, R. V.; SILVA, S. L. F.; VIÉGAS, R. A.; SILVEIRA, J. A. G. Salt stress induced damages on the photosynthesis of physic nut young plants. Scientia Agrícola, Piracicaba, v. 68, n.1, p.62-68, 2011. http://dx.doi.org/10.1590/S0103-90162011000100010.

SILVA, E. N. da; SILVEIRA, J. A. G.; RODRIGUES, C. R. F.; LIMA, C. S. de; VIÉGAS, R. A. Contribuição de solutos orgânicos e inorgânicos no ajustamento osmótico de pinhão-manso submetido à salinidade. Pesquisa Agropecuária Brasileira, Brasília, v.44, n.5, p.437-445, 2009. http://dx.doi.org/10.1590/S0100204X2009000500002.

TAIZ, L.; ZEIGER, E. Fisiologia vegetal. 5.ed. Porto Alegre: Artmed, 2013. 918 p.

VIANA, E. M.; KIEHL, J. de C. Doses de nitrogênio e potássio no crescimento do trigo. Bragantia, Campinas, v.69, n.4, p.975-982, 2010. http://dx.doi.org/10.1590/S0006-87052010000400024. 